\title{
Picocyanobacteria abundance in relation to growth and loss rates in oligotrophic to mesotrophic lakes
}

\author{
Brigitte F. Lavallée, Frances R. Pick* \\ Ottawa Carleton Institute of Biology, University of Ottawa, Ottawa, Ontario K1N 6N5, Canada
}

\begin{abstract}
The relative importance of growth versus loss rates of picocyanobacteria (PC) and the influence of physical and chemical variables on their in situ abundance were examined during summer 2000 in 48 lakes in Quebec, Ontario and New York State. The lakes were selected based on their trophic state. For the resulting range in total phosphorus (TP) (1 to $\left.42 \mu \mathrm{g} \mathrm{l}^{-1}\right)$, PC abundance varied from $<10^{2} \mathrm{ml}^{-1}$ in a eutrophic lake dominated by a cyanobacterial bloom to over $10^{5} \mathrm{ml}^{-1}$ in oligotrophic and more mesotrophic lakes. Growth rates on average exceeded loss rates in the lakes with maximum rates of 1.93 and $1.25 \mathrm{~d}^{-1}$, respectively, as estimated using a selective metabolic inhibitor method. On average the doubling time of PC was about $1.7 \mathrm{~d}$. Growth rates were positively correlated with loss rates in the lakes. The multiple regression model that explained the most variation in PC abundance included SRP, loss rates, conductivity and the ratio of total Kjeldahl nitrogen (TKN) to TP. The results suggest that biotic control of the abundance of PC may be as important as abiotic control. However, the model could only explain $44 \%$ of the variation in PC abundance among the lakes. This could be in part the result of considering PC as one ecological group when in fact considerable diversity is likely present among freshwater PC.
\end{abstract}

KEY WORDS: Picocyanobacteria · Lake trophy · Growth rate $\cdot$ Loss rate $\cdot$ Grazing $\cdot$ Selective metabolic inhibitor technique

\section{INTRODUCTION}

Autotrophic picoplankton (APP; cells 0.2 to $2 \mu \mathrm{m}$ in diameter) contribute significantly to the primary productivity of lakes and oceans (reviews of Stockner \& Antia 1986, Weisse 1993, Raven 1998, Stockner et al. 2000). APP are also an important link in the microbial loop (Azam et al. 1983) and are subject to intense grazing pressure by heterotrophic organisms of the plankton. Grazing is primarily due to small heterotrophic nanoflagellates (2 to $20 \mu \mathrm{m}$ ), and larger rotifers and ciliates (20 to $200 \mu \mathrm{m})$ (e.g. Weisse 1988, Hall et al. 1993). Other losses for APP may include viral lysis (Suttle \& Chan 1994) and cell death. However, because of their small dimensions, losses due to sedimentation are considered negligible (Weisse 1993).

\footnotetext{
*Corresponding author. E-mail: frpick@science.uottawa.ca
}

Cyanobacteria of picoplanktonic size (picocyanobacteria [PC]) usually dominate the abundance of APP in lakes, with eukaryotic cells occasionally dominating in terms of biomass depending on the season (Pick \& Agbeti 1991, Fahnenstiel \& Carrick 1992, Gaedke \& Weisse 1998). PC can be rod shaped, represented by the genus Synechococcus, or coccoid, as represented by Synechocystis spp. (Rippka 1988, but see Komárek 1996). Two main pigment groups can be distinguished in lakes based on the presence or absence of the accessory pigment phycoerythrin (Pick 1991, Vörös et al. 1998). Because of their high surface to volume ratio, $\mathrm{PC}$ are efficient at nutrient uptake at low nutrient concentrations. This property likely provides PC with a competitive advantage in oligotrophic systems relative to larger phytoplankton including bloom forming cyanobacteria (Raven 1998, Agawin et al. 2000).

Not all physical or chemical variables affect phytoplankton to the same extent. With respect to PC, previ- 
ous studies have outlined the importance of light (Pick 1991, Vörös et al. 1998), temperature (Pick \& Caron 1987, Ning \& Vaulot 1992, Agawin et al. 1998), nitrogen and phosphorus (Wehr 1989, Stockner \& Shortreed 1991, Vörös et al. 1998, Rhew \& Ochs 2000), and grazing (Wehr 1991, Müller 1996, Gaedke \& Weisse 1998) on their abundance and composition in lakes and oceans. These studies have usually focused on 1 or 2 variables at a time and not the whole environment of PC. As a result, the importance of each of these effects separately and in combination is not clear.

While initially PC were noted in clear oligotrophic lakes and oceans, more comprehensive surveys have shown that they can be present in eutrophic systems as well. Pick (2000) showed that PC abundance in Canadian and New Zealand lakes increased with trophic status as measured by total phosphorus (TP) in the water, from oligotrophy $\left(<15 \mathrm{\mu g} \mathrm{l}^{-1}\right)$ to mesotrophy (15 to $20 \mathrm{\mu g} \mathrm{l}^{-1}$ ), where the abundance reached a plateau and then decreased in hypereutrophic systems $\left(>100 \mathrm{\mu g} \mathrm{l}^{-1}\right)$. However, the data of Stockner \& Shortreed (1991) on lakes in British Columbia, Canada, and that of Søndergaard (1991) on European lakes taken together do not show any trend between PC abundance and the same range of TP (Pick 2000). Similarly, Vörös et al. (1998) found no simple relationship between PC abundance and chlorophyll a (chl a) concentrations along a wide trophic gradient of lakes including some fish ponds. In a recent major review of the ecology of PC, Stockner et al. (2000) concluded that the pattern of PC abundance across trophic gradients remains poorly understood and that a simple 2 variable model ( $\mathrm{PC}$ versus chl a) is clearly inadequate to explain or predict $\mathrm{PC}$ abundance and distribution.

The purpose of this study was to determine (1) whether PC abundance could be predicted for lakes by physical and chemical variables of these systems and, particularly, whether trophic status as determined by the total concentration of phosphorus was a significant predictor; and (2) which physical and chemical variables correlated with PC growth and loss rates in the same lakes. While the physical and chemical variables pertinent to algal growth must be considered in order to explain the distribution of $\mathrm{PC}$, it is the balance between growth and loss processes that ultimately determines observed cell concentrations. We hypothesised that both PC growth and loss would increase with nutrient availability and trophic state. However, at some level of trophy, growth rates would reach a maximum while loss rates would keep increasing. At this intermediate level of nutrient availability, we hypothesised that the balance between growth and loss would become negative, leading to a decline in PC abundance with increasing trophy.

\section{MATERIALS AND METHODS}

Study sites and sampling. Forty-eight lakes were sampled once from July 17 to August 29, 2000; 2 lakes, Bob's and Memphremagog, were sampled in 2 bays, which had differences in physical and chemical variables. This gave a total of 50 sites (Table 1). These lakes were located in the Canadian provinces of Ontario (Rideau Lakes district) and Quebec (3 regions: Estrie, Laurentians and Outaouais) and in the USA in New York State. Lakes were chosen on the basis of their concentration of $\mathrm{TP}$, in order to obtain as wide a range of values as possible in the sampling area. An integrated sample of the epilimnion was taken in the middle of the lake or in the deepest area with a $2.5 \mathrm{~cm}$ diameter Tygon tube with a weight attached at the end. Samples were taken between 11:00 and 14:00 h. Water was kept in a $9 \mathrm{l}$ polyethylene carboy in a cooler until processed no later than 16:00 $\mathrm{h}$ on the same day. Water transparency was measured with a $20 \mathrm{~cm}$ diameter Secchi disk. Photosynthetically active radiation (PAR) measurements were taken every $0.5 \mathrm{~m}$ with a LICOR LI-185 quantum radiometer. For lakes sampled in Ontario, the Laurentians and Outaouais (except lakes Constance, Forgeron, Mackay and Vert), temperature and conductivity were measured in situ with a YSI model $33 \mathrm{~S}-\mathrm{C}-\mathrm{T}$ probe and $\mathrm{pH}$ with an Oakton Waterproof pHTestr2. For lakes in New York, Estrie, and 4 in the Outaouais, the 3 variables were measured in situ with a Hydrolab Minisonde $4 a$. The equipment was calibrated at the beginning of the sampling period.

Nutrient analyses and chl a. Duplicate water samples at each site were analysed for TP, soluble reactive phosphorus (SRP), total Kjeldahl nitrogen (TKN), ammonium and nitrite + nitrate by the Regional Municipality of Ottawa-Carleton, Surface Water Quality Branch, Ottawa, Ontario. TP was analysed by acid digestion followed by the molybdate ascorbic acid

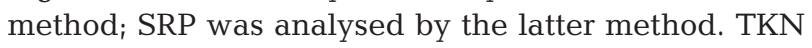
was determined by Kjeldahl acid digestion; nitrite and nitrate were determined by the US Environmental Protection Agency (EPA) method 300.0 using ion chromatography; ammonium was determined by automated colorimetry (phenat/nitroprusside/hypochlorite procedure) (Regional Municipality of Ottawa-Carleton 1993). Samples were filtered for chl a on Nuclepore polycarbonate filters $(4.7 \mathrm{~cm}$ diameter) of $0.2 \mu \mathrm{m}$ pore size (total chl a) and $2 \mu \mathrm{m}$ pore size in duplicate. Filters were kept frozen $\left(-20^{\circ} \mathrm{C}\right)$ until extraction. Total chl a corresponds to the $0.2 \mu \mathrm{m}$ fraction of chlorophyll while chl a associated with APP corresponds to the total chlorophyll $0.2 \mu \mathrm{m}$ fraction minus the $2 \mu \mathrm{m}$ fraction. Thawed filters were extracted with $4 \mathrm{ml}$ of dimethyl sulfoxide (DMSO) and incubated at $60^{\circ} \mathrm{C}$ for $10 \mathrm{~min}$, 
Table 1. Location, morphometry and picocyanobacteria (PC) abundance determined by epifluorescence microscopy $(\mathrm{n}=3)$ in 48 lakes sampled once in July or August 2000. LAC: light attenuation coefficient; SA: surface area; SD: standard deviation; Temp.: temperature; $Z_{\max }$ : maximum depth

\begin{tabular}{|c|c|c|c|c|c|c|c|c|}
\hline $\begin{array}{l}\text { Region/ } \\
\text { Lake }\end{array}$ & Latitude & Longitude & $\begin{array}{c}\mathrm{SA} \\
\left(\mathrm{km}^{2}\right)\end{array}$ & $\begin{array}{l}Z_{\max } \\
(\mathrm{m})\end{array}$ & $\begin{array}{l}\text { Secchi disk } \\
\text { depth }(\mathrm{m})\end{array}$ & LAC & $\begin{array}{l}\text { Temp. } \\
\left({ }^{\circ} \mathrm{C}\right)\end{array}$ & $\begin{array}{l}\text { PC abundance } \\
\pm \mathrm{SD}\left(10^{4} \mathrm{l}^{-1}\right)\end{array}$ \\
\hline \multicolumn{9}{|c|}{ Outaouais, Quebec } \\
\hline Argile & $45^{\circ} 52^{\prime}$ & $75^{\circ} 34^{\prime}$ & 4.51 & 43 & 3.00 & 0.62 & 22 & $3.52(0.44)$ \\
\hline Barrière & $45^{\circ} 53^{\prime}$ & $75^{\circ} 06^{\prime}$ & 3.11 & 73 & 4.25 & 0.43 & 20 & $4.11(0.10)$ \\
\hline Black & $45^{\circ} 29^{\prime}$ & $75^{\circ} 51^{\prime}$ & 0.01 & 9.5 & 2.75 & 0.68 & 21 & $0.53(0.13)$ \\
\hline Forgeron & $46^{\circ} 03^{\prime}$ & $75^{\circ} 37^{\prime}$ & 0.55 & 38.0 & 2.75 & 0.84 & 19.5 & $0.99(0.38)$ \\
\hline Mulvihill & $45^{\circ} 29^{\prime}$ & $75^{\circ} 51^{\prime}$ & 0.01 & 3.7 & 2.75 & 0.62 & 21 & $4.74(0.06)$ \\
\hline Orignal & $45^{\circ} 52^{\prime}$ & $75^{\circ} 35^{\prime}$ & 0.37 & 13.3 & 4.50 & 0.33 & 24 & $3.88(0.76)$ \\
\hline Philippe & $45^{\circ} 36^{\prime}$ & $76^{\circ} 01^{\prime}$ & 1.76 & 17.4 & 4.25 & 0.59 & 24 & $17.30(1.05)$ \\
\hline Renaud & $45^{\circ} 36^{\prime}$ & $76^{\circ} 02^{\prime}$ & 0.10 & 4.3 & 2.00 & 0.70 & 23 & $1.04(0.24)$ \\
\hline Simon & $45^{\circ} 55^{\prime}$ & $75^{\circ} 04^{\prime}$ & 30.73 & 108 & 4.50 & 0.39 & 19 & $3.56(0.18)$ \\
\hline Taylor & $45^{\circ} 36^{\prime}$ & $76^{\circ} 03^{\prime}$ & 0.60 & 12.2 & 4.00 & 0.42 & 24 & $6.73(0.99)$ \\
\hline Vert & $45^{\circ} 54^{\prime}$ & $75^{\circ} 36^{\prime}$ & 0.24 & 25.3 & 4.50 & 0.82 & 21 & $8.90(0.36)$ \\
\hline \multicolumn{9}{|l|}{ Ottawa, Ontario } \\
\hline Constance & $45^{\circ} 24^{\prime}$ & $75^{\circ} 58^{\prime}$ & 1.45 & 4.0 & 1.50 & 1.07 & 20 & $46.80(6.23)$ \\
\hline MacKay & $45^{\circ} 27^{\prime}$ & $75^{\circ} 40^{\prime}$ & 0.79 & 13 & 4.75 & 0.64 & 23 & $17.10(7.20)$ \\
\hline \multicolumn{9}{|c|}{ Rideau lakes, Ontario } \\
\hline Big Rideau & $44^{\circ} 42^{\prime}$ & $76^{\circ} 13^{\prime}$ & 5.8 & 95 & 5.75 & 0.41 & 24.5 & $13.70(0.51)$ \\
\hline Bob's & & & 9.0 & 23 & & & & \\
\hline (Green Bay) & $44^{\circ} 38^{\prime}$ & $76^{\circ} 35^{\prime}$ & & & 6.25 & 0.35 & 25.0 & $8.30(0.09)$ \\
\hline (West Bay) & $44^{\circ} 39^{\prime}$ & $76^{\circ} 37^{\prime}$ & & & 4.50 & 0.50 & 24.0 & 20.60 (5.19) \\
\hline Indian & $44^{\circ} 35^{\prime}$ & $76^{\circ} 19^{\prime}$ & 2.66 & 26 & 3.10 & 0.57 & 23.0 & $14.60(2.77)$ \\
\hline Jack's & $44^{\circ} 41^{\prime}$ & $78^{\circ} 04^{\prime}$ & 5.10 & 44 & 5.00 & 0.44 & 22.0 & $12.00(1.09)$ \\
\hline Opinicon & $44^{\circ} 33^{\prime}$ & $76^{\circ} 20^{\prime}$ & 7.85 & 9.2 & 4.40 & 0.75 & 23.5 & $10.80(0.59)$ \\
\hline Otter & $44^{\circ} 46^{\prime}$ & $76^{\circ} 07^{\prime}$ & 5.71 & 37 & 3.00 & 0.58 & 23.5 & $22.70(2.91)$ \\
\hline Upper Rideau & $44^{\circ} 40^{\prime}$ & $76^{\circ} 21^{\prime}$ & 13.62 & 22 & 3.20 & 0.71 & 22.5 & $8.56(0.87)$ \\
\hline Upper Rock & $44^{\circ} 29^{\prime}$ & $76^{\circ} 24^{\prime}$ & 0.76 & 44.5 & 4.25 & 0.45 & 24.0 & $9.75(1.68)$ \\
\hline Westport Sand & $44^{\circ} 40^{\prime}$ & $76^{\circ} 25^{\prime}$ & 2.08 & 12.8 & 6.00 & 0.49 & 23.0 & $15.50(0.90)$ \\
\hline Wolfe & $44^{\circ} 40^{\prime}$ & $76^{\circ} 29^{\prime}$ & 7.5 & 31 & 4.20 & 0.42 & 23.5 & $18.10(1.87)$ \\
\hline \multicolumn{9}{|c|}{ Laurentians, Quebec } \\
\hline Achigan & $45^{\circ} 56^{\prime}$ & $73^{\circ} 57^{\prime}$ & 5.32 & 26 & 3.50 & 0.65 & 23.0 & $6.99(1.23)$ \\
\hline Anne & $45^{\circ} 49^{\prime}$ & $74^{\circ} 18^{\prime}$ & 1.18 & 22 & 4.50 & 0.58 & 23.0 & $13.30(3.50)$ \\
\hline Connelly & $45^{\circ} 53^{\prime}$ & $73^{\circ} 57^{\prime}$ & 1.21 & 20 & 3.25 & 0.62 & 24.0 & $2.54(1.82)$ \\
\hline Croche & $45^{\circ} 59^{\prime}$ & $74^{\circ} 00^{\prime}$ & 0.18 & 11 & 3.25 & 0.81 & 24.0 & $8.31(1.20)$ \\
\hline En coeur & $45^{\circ} 58^{\prime}$ & $74^{\circ} 00^{\prime}$ & 0.47 & 8 & 3.25 & 0.62 & 23.0 & $1.54(0.41)$ \\
\hline Hugues & $45^{\circ} 48^{\prime}$ & $74^{\circ} 15^{\prime}$ & & & 3.25 & 0.64 & 22.0 & $6.86(1.72)$ \\
\hline Morency & $45^{\circ} 55^{\prime}$ & $74^{\circ} 02^{\prime}$ & 0.26 & 20 & 7.50 & 0.22 & 23.0 & $9.36(0.95)$ \\
\hline Montaubois & $45^{\circ} 55^{\prime}$ & $74^{\circ} 04^{\prime}$ & 0.16 & 32 & 6.25 & 0.27 & 22.5 & $1.81(0.61)$ \\
\hline Ours & $45^{\circ} 57^{\prime}$ & $74^{\circ} 03^{\prime}$ & 0.14 & 17 & 2.25 & 1.30 & 23.0 & $8.21(1.51)$ \\
\hline Pin rouge & $45^{\circ} 57^{\prime}$ & $74^{\circ} 02^{\prime}$ & 0.15 & 13 & 1.75 & 2.45 & 23.0 & $2.88(0.38)$ \\
\hline \multicolumn{9}{|l|}{ Estrie, Quebec } \\
\hline d'Argent & $45^{\circ} 18^{\prime}$ & $72^{\circ} 18^{\prime}$ & 1.0 & 15.6 & 2.50 & 0.80 & 22.5 & $14.10(0.88)$ \\
\hline Bowker & $45^{\circ} 42^{\prime}$ & $72^{\circ} 21^{\prime}$ & 2.5 & 57.9 & 5.25 & 0.31 & 21.0 & $2.12(0.42)$ \\
\hline Brome & $45^{\circ} 14^{\prime}$ & $72^{\circ} 30^{\prime}$ & 14.39 & 12.2 & 1.50 & 1.13 & 22.0 & $45.60(2.85)$ \\
\hline Brompton & $45^{\circ} 42^{\prime}$ & $72^{\circ} 14^{\prime}$ & 11.9 & 42.3 & 3.25 & 0.66 & 21.5 & $0.99(0.05)$ \\
\hline Choinière & $45^{\circ} 25^{\prime}$ & $72^{\circ} 37^{\prime}$ & 4.75 & & 2.25 & 0.90 & 22.0 & $5.09(1.18)$ \\
\hline Fraser & $45^{\circ} 38^{\prime}$ & $72^{\circ} 17^{\prime}$ & 1.6 & 19.8 & 4.75 & 0.59 & 22.0 & $0.46(0.01)$ \\
\hline Lovering & $45^{\circ} 17^{\prime}$ & $72^{\circ} 15^{\prime}$ & 4.94 & 22.9 & 3.25 & 0.69 & 22.5 & $3.27(0.47)$ \\
\hline Magog & $45^{\circ} 30^{\prime}$ & $72^{\circ} 04^{\prime}$ & 10.95 & 19.2 & 3.75 & 0.57 & 23.0 & $3.98(1.24)$ \\
\hline Massawippi & $45^{\circ} 21^{\prime}$ & $72^{\circ} 00^{\prime}$ & 17.9 & 84.9 & 3.50 & 0.51 & 23.0 & $3.58(0.82)$ \\
\hline Memphrémagog & & & 97.9 & & & & & \\
\hline (Magog Bay) & $45^{\circ} 16^{\prime}$ & $72^{\circ} 11^{\prime}$ & & 33.5 & 6.00 & 0.48 & 22.5 & $1.33(0.22)$ \\
\hline (Sargent Bay) & $45^{\circ} 10^{\prime}$ & $72^{\circ} 17^{\prime}$ & & & 6.00 & 0.41 & 23.0 & $3.33(0.51)$ \\
\hline Montjoie & $45^{\circ} 40^{\prime}$ & $72^{\circ} 10^{\prime}$ & 3.3 & 21.3 & 3.25 & 0.63 & 22.0 & $1.14(0.16)$ \\
\hline Stukely & $45^{\circ} 18^{\prime}$ & $72^{\circ} 16^{\prime}$ & 4.0 & 30.5 & 3.25 & 0.50 & 21.5 & $29.40(4.76)$ \\
\hline Orford & $45^{\circ} 22^{\prime}$ & $72^{\circ} 15^{\prime}$ & 1.29 & 39.5 & 3.25 & 0.45 & 22.0 & $6.76(0.62)$ \\
\hline \multicolumn{9}{|l|}{ New York State } \\
\hline Oneida & $43^{\circ} 06^{\prime}$ & $76^{\circ} 13^{\prime}$ & 210 & 16.7 & 1.50 & 1.84 & 22.5 & $<0.01$ \\
\hline Onondaga & $43^{\circ} 14^{\prime}$ & $75^{\circ} 48^{\prime}$ & 12 & 19.5 & 1.60 & 0.69 & 23.5 & $15.10(2.33)$ \\
\hline
\end{tabular}


then re-filtered with $21 \mathrm{ml}$ of $90 \%$ acetone (Burnison 1980). Chl a fluorescence was measured with a Turner Designs fluorometer and calibrated by spectrophotometry using the trichromatic equation of Jeffrey \& Humphrey (1975).

Growth and loss rates experiments. The growth rate of microorganisms can be determined by the following logistic equation:

$$
N_{t}=N_{0} \mathrm{e}^{r t}
$$

where $N_{t}$ and $N_{0}$ represent the abundance of cells at times $t$ and 0 and $r$ is rate of increase. The rate of increase of microorganisms in situ $(r)$ is the result of the balance between the intrinsic growth $(k)$ and various loss processes such as natural senescence, viral lysis, and grazing by protozoans and zooplankton. Measurements of growth and loss rates were estimated by the following equation:

$$
r=k-g=\ln \left(N_{t} / N_{0}\right) / t
$$

where $r$ is the apparent rate of increase or decrease of the microorganism, $k$ is their intrinsic growth rate, $g$ is their loss rate, and $N_{t}$ and $N_{0}$ represent the abundance of organisms at times $t(24 \mathrm{~h})$ and 0 . At each site, the loss rate was measured from the change in abundance of PC after $24 \mathrm{~h}$ of incubation in the presence of ampicillin; this assumes that PC growth $k$ was zero during the incubation since the antibiotic was present $(r=-g)$. Ampicillin blocks cell division in cyanobacteria (and some heterotrophic bacteria) by inhibiting cell wall synthesis; the concentrations used do not inhibit eukaryotes (Campbell \& Carpenter 1986, Ning \& Vaulot 1992). In addition to ampicillin, we tested kanamycin as an alternate antibiotic (Liu et al. 1995). However, we found that kanamycin interfered with glutaraldehyde preservation as treated samples became coloured and cells were more difficult to enumerate by epifluorescence. Apparent growth rates $(r)$ were determined by using the apparent increase of $\mathrm{PC}$ over $24 \mathrm{~h}$ in control treatments.

Water samples from each site were pre-screened with a $250 \mu \mathrm{m}$ mesh size net if large cladocerans (Daphnia spp.) were observed in the samples; they were then incubated for $24 \mathrm{~h}$ in triplicate $300 \mathrm{ml}$ polycarbonate Erlenmeyer flasks completely filled without leaving any headspace. The flasks were placed in a plastic cage and immersed in a water tank in the greenhouse of the University of Ottawa, Ontario, within a $2 \mathrm{~h}$ drive of the campus. For lakes a great distance away from the laboratory, the water samples were placed in a plastic cage and immersed in situ near the shore of the lake located close to a biological station. For both incubation methods, the depth of immersion of the cage was adjusted to correspond to the average light regimen for maximum PC growth
(100 to $300 \mu \mathrm{E} \mathrm{m}{ }^{-2} \mathrm{~s}^{-1}$ ) based on culture experiments (Stockner et al. 2000). These light levels also correspond to maximum photosynthetic rates in natural populations. Treatment flasks contained $5 \mathrm{mg} \mathrm{l}^{-1}$ of ampicillin (Sigma Chemical); the control flasks contained lake water only. Subsamples of $18 \mathrm{ml}$ were taken at Time 0 and at $24 \mathrm{~h}$ from each Erlenmeyer flask, and $2 \mathrm{ml}$ of $10 \%$ glutaraldehyde buffered with sodium cacodylate was added for a final concentration of $1 \%$ glutaraldehyde. Samples were kept in the dark at $4{ }^{\circ} \mathrm{C}$ until enumeration a few weeks later.

Enumeration of PC. Between 2 and $10 \mathrm{ml}$ of preserved water was filtered at low vacuum (less than $200 \mathrm{~mm} \mathrm{Hg}$ ) on a Nuclepore $0.2 \mu \mathrm{m}$ pore size filter with a Millipore $0.45 \mu \mathrm{m}$ pore size backing filter under the former to ensure an even distribution of the cells. PC were identified and enumerated with a Zeiss Jenamed 2 epifluorescence microscope equipped with a blue excitation filter (450 to $490 \mathrm{~nm}$, barrier filter $520 \mathrm{~nm}$ ) and a green excitation filter (510 to $560 \mathrm{~nm}$, barrier filter $590 \mathrm{~nm}$ ). The green filter was used to count the total abundance of PC while the blue filter was used for qualitative assessment of those PC containing phycoerythrin as well as eukaryotic picoplankton (Pick 1991). Enumeration was done at $1250 \times$ magnification where 15 randomly chosen fields were counted to obtain a minimum of 300 cells.

Statistical analysis. PC abundance, chl $a$, and physical and chemical variables (except the TKN:TP ratio, $\mathrm{pH}$, light attenuation coefficient [LAC] and temperature) required log transformation in order to satisfy homogeneity and normality of the residuals. Pearson correlations of growth and loss rates of PC with physical and chemical variables were performed with Systat 10 (SPSS). Multiple regression analyses of interactions and effects of variables on the in situ PC abundance, including forward and backward procedures, were performed in order to provide the most appropriate predictive model of PC abundance across the lakes.

\section{RESULTS}

\section{Physical and chemical variables among lakes}

The majority of the 48 lakes (or 50 sites) were deep enough to be thermally stratified during summer with the exception of 3 lakes that had maximum depths of about $4 \mathrm{~m}$ (Constance, Mulvihill, Renaud) (Table 1). The epilimnion depth varied from 2 to $5 \mathrm{~m}$ and epilimnetic temperatures varied from 19 to $25^{\circ} \mathrm{C}$. Secchi depth values ranged from 1.5 to $7.5 \mathrm{~m}$. In most lakes the euphotic zone exceeded the mixed layer depth. Exceptions were the more eutrophic lakes such as Onondaga, Oneida, Constance and a couple of slightly 
Table 2. Chemical characteristics of temperate lakes sampled in summer $2000(\mathrm{n}=50)$. APP: autotrophic picoplankton; chl a: cholorophyll $a_{i}$ SRP: soluble reactive phosphorus; TKN: total Kjeldahl nitrogen; TP: total phosphorus

\begin{tabular}{|lcccc|}
\hline Variable & Minimum & Median & Maximum & Mean \\
\hline $\mathrm{pH}$ & 6.4 & 8.2 & 9.1 & 8.1 \\
$\mathrm{Conductivity}\left(\mu \mathrm{S} \mathrm{cm}^{-1}\right)$ & 20 & 159 & 1809 & 194 \\
$\mathrm{TP}\left(\mu \mathrm{g} \mathrm{l}^{-1}\right)$ & 1.0 & 9.0 & 42.0 & 11.7 \\
$\mathrm{SRP}\left(\mu \mathrm{g} \mathrm{l}^{-1}\right)$ & 0.5 & 2.0 & 9.0 & 2.9 \\
$\mathrm{TKN}\left(\mu \mathrm{g} \mathrm{l}^{-1}\right)$ & 149 & 330 & 900 & 374 \\
$\mathrm{NH}_{3}\left(\mu \mathrm{g} \mathrm{l}^{-1}\right)$ & 1.0 & 6.0 & 127 & 10.5 \\
$\mathrm{NO}_{2}+\mathrm{NO}_{3}\left(\mu \mathrm{g} \mathrm{l}^{-1}\right)$ & 3.0 & 3.0 & 1115 & 40 \\
$\mathrm{Total} \mathrm{chl} \mathrm{a}\left(\mu \mathrm{g} \mathrm{l}^{-1}\right)$ & 1.83 & 5.43 & 68.98 & 8.74 \\
$\mathrm{APP} \mathrm{chl} a\left(\mu \mathrm{g} \mathrm{l}^{-1}\right)$ & 0.06 & 0.93 & 11.40 & 1.54 \\
\hline
\end{tabular}

dystrophic or brown water lakes (e.g. Renaud, Forgeron).

While the lakes were not selected to encompass a range of $\mathrm{pH}$ values, a few lakes were slightly acidic (e.g. Pin Rouge at $\mathrm{pH}$ 6.4) and others quite alkaline (e.g. Mackay at pH 9.3 and Oneida at pH 9.1). On average the lakes were slightly alkaline (Table 2). The lakes ranged considerably in conductivity from as low as 20 to $80 \mu \mathrm{S} \mathrm{cm}^{-1}$ for lakes on the Canadian Shield (e.g. Croche, Simon). Lakes of intermediate conductivity dominated the Rideau Lakes district. Onondaga had the highest conductivity $\left(1809 \mu \mathrm{S} \mathrm{cm}^{-1}\right)$, very much beyond the range found in the other lakes (20 to $420 \mu \mathrm{S}$ $\left.\mathrm{cm}^{-1}\right)$.

Epilimnetic TP values ranged from 1 to $42 \mu \mathrm{g} \mathrm{l^{-1 }}$ and epilimnetic TKN varied from 149 to $900 \mu \mathrm{g} \mathrm{l}^{-1}$ with median values of $9 \mu \mathrm{g} \mathrm{l}^{-1}$ and $330 \mu \mathrm{g} \mathrm{l}^{-1}$, respectively (Table 2). The lakes all had TKN:TP ratios above 20. The most eutrophic lakes were Oneida in New York State and Constance in Eastern Ontario, with TP concentrations of 42 and $40 \mu \mathrm{g} \mathrm{l}^{-1}$, respectively. Several lakes can be considered ultra-oligotrophic (Simon, Bowker, Orford, Stukely) with TP concentrations of 1 to $2 \mu \mathrm{g}^{-1}$. These lakes also had very high TKN:TP ratios $(>100)$.

Dissolved inorganic forms of nitrogen and phosphorus were generally at very low concentrations (Table 2). SRP ranged from the detection limits of the analytical method $\left(0.5 \mu \mathrm{g} \mathrm{l}^{-1}\right)$ to a maximum of $9.0 \mu \mathrm{g}$ $\mathrm{l}^{-1}$ in Otter. Ammonium ranged from detection $(3.0 \mu \mathrm{g}$ $\mathrm{l}^{-1}$ ) to a maximum of $27 \mu \mathrm{g}^{-1}$ in Forgeron. Nitrate and nitrite ranged from detection $\left(3.0 \mu \mathrm{g} \mathrm{l}^{-1}\right)$ to a maximum of $1115 \mu \mathrm{g} \mathrm{l}^{-1}$ in Onondaga Lake. The highest concentrations of total dissolved inorganic nitrogen forms were also found in the latter lake.

Total chl a ranged from $1.83 \mu \mathrm{g} \mathrm{l}^{-1}$ in Simon to $68.98 \mu \mathrm{g} \mathrm{l}^{-1}$ in Oneida, while the chlorophyll in the picoplankton fraction $(<2 \mu \mathrm{m})$ ranged from $0.06 \mu \mathrm{g} \mathrm{l}^{-1}$ in Indian to $11.40 \mathrm{\mu g}^{-1}$ in Oneida (Table 2).
Table 3 provides the Pearson correlation matrix for all the variables and indicates how closely related some of the variables are to each other. As might be expected, there were significant correlations based on Bonferroni adjusted probabilities among some of the chemical and physical variables. Log transformed TP, $\log$ TKN, the TKN:TP ratio and log totalchla were all highly correlated with one another $(p<0.001)$. SRP was significantly and positively correlated with $\log$ TKN as well as $\mathrm{pH}(\mathrm{p}<0.001)$ and slightly correlated with TP $(p<0.01)$. The inorganic forms of nitrogen did not appear to be correlated with any other single variable.

The variables related to the light climatethat is, the Secchi disk depth (log transformed) and the LAC - as well as log total chl a were significantly correlated with one another. Both log Secchi depth and LAC showed stronger correlations with TKN than TP. Interestingly, when chl $a$ in the APP fraction was included, there was no significant linear relationship between APP chl a and TP or even PC abundance (data not included in Table 3).

\section{PC: growth and loss rates}

The APP assemblage was dominated by PC in all lakes sampled. Abundance of PC in situ varied from traces $\left(<100 \mathrm{ml}^{-1}\right.$ in Oneida Lake, New York State) to a maximum in Constance Lake of $4.68 \times 10^{5} \mathrm{ml}^{-1}$ (Table 1). Although there was a trend of increasing PC with TP over the range of 1 to $42 \mu \mathrm{g} \mathrm{l}^{-1}$, it was not statistically significant (Fig. 1, Table 3). Oneida Lake was unique in that it had $\mathrm{PC}$ concentrations almost 2 orders

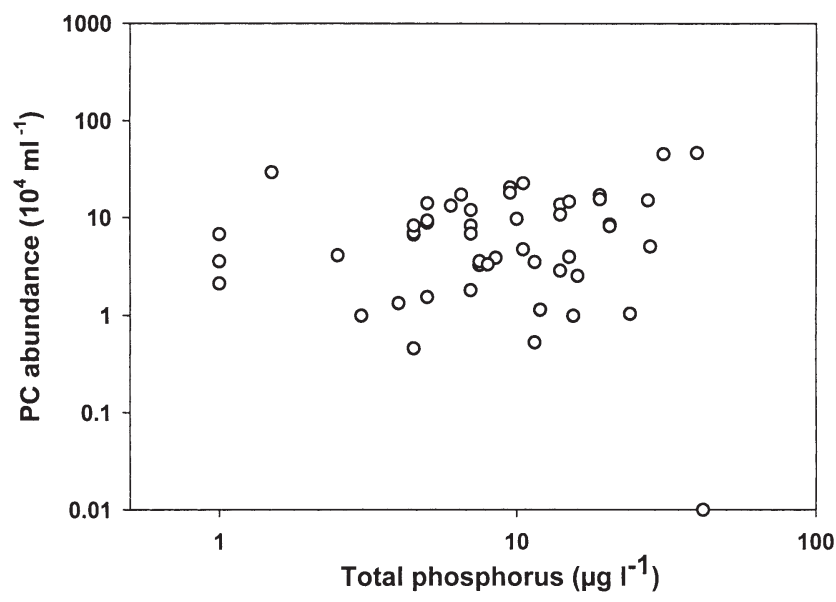

Fig. 1. Scatter plot of the logarithm of picocyanobacteria (PC) abundance versus the logarithm of epilimnetic total phosphorus concentrations for 50 lake sites during summer 2000 


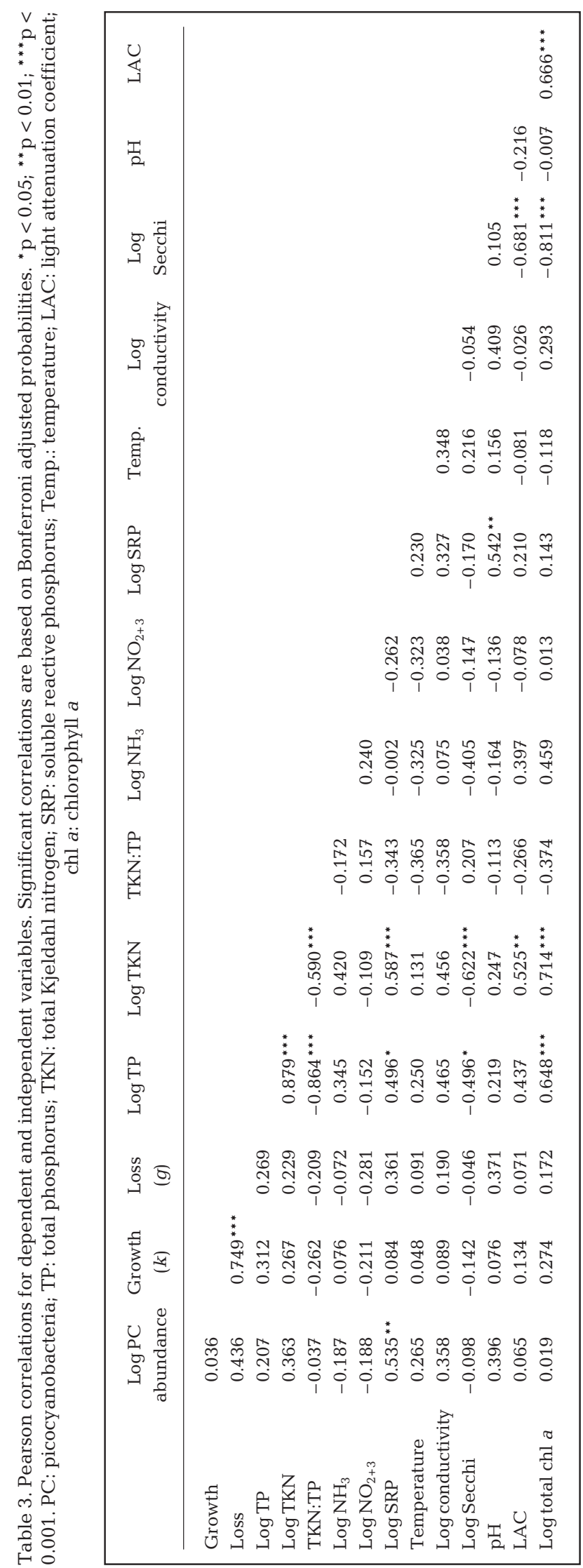

of magnitude lower than the other lakes, whereas Constance with a similar TP concentration had the maximum observed PC concentration (Table 1).

Among all the variables considered, only SRP showed a statistically significant linear relationship with PC ( $p<0.01)$, and the relationship was positive (Table 3). The PC loss rates and $\mathrm{pH}$ also showed positive but weak relationships with $\mathrm{PC}$.

Among the 50 sites, the estimated intrinsic growth rates of $\mathrm{PC}$ ranged from $-0.31 \mathrm{~d}^{-1}$ to $1.93 \mathrm{~d}^{-1}$ (in ln units $\mathrm{d}^{-1}$ ) and averaged $0.41 \mathrm{~d}^{-1}$ across the lakes. As a result, the generation time or doubling time of PC in these lakes averaged approximately $1.7 \mathrm{~d}$. Loss rates ranged from -0.33 to $1.25 \mathrm{~d}^{-1}$ and averaged $0.26 \mathrm{~d}^{-1}$ across the lakes. Since only traces of PC were found in Oneida Lake, growth or loss rates could not be estimated for that lake. Growth and loss rates of PC tended to increase with TP, but the relationships were not significant, although the correlation coefficients were among the highest (Table 3). Neither growth nor loss showed a significant linear trend with TKN or other nutrient forms.

Growth and loss rates of PC were highly correlated among the lakes, and loss rate increased positively with growth rate $(p<0.001$; Table 2$)$. The $1: 1$ line in Fig. 2 shows that loss rates were on average lower than growth rates (slope $=0.67, \mathrm{p}=0.0002$ ) .

\section{Predicting in situ PC abundance}

Among the physical and chemical variables, the most significant linear relationship of in situ PC abundance with a single predictor was with SRP $(p<0.01)$.

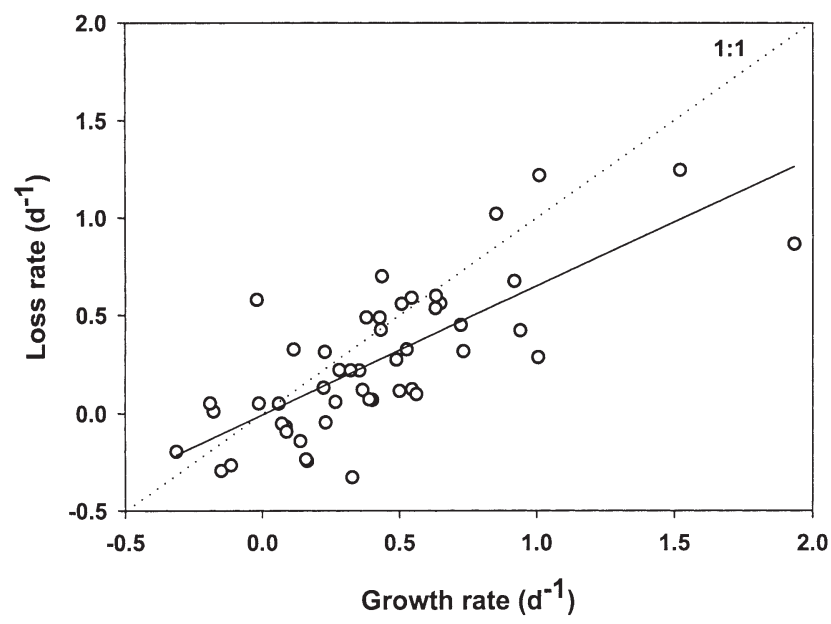

Fig. 2. Relationship between growth and loss rates $\left(\mathrm{d}^{-1}\right)$ of PC $(\mathrm{r}=0.75, \mathrm{n}=49, \mathrm{p}<0.001)$ for 49 lake sites. Each point represents triplicate samples from an individual lake sampled once during the summer 
It is worth noting that SRP itself was highly correlated with $\mathrm{pH}$ and to a lesser extent with TP (Table 3). In order to best explain the abundance of PC in lakes, multiple regressions were performed with as many of the independent variables as possible. However, the models included only variables that were not highly correlated with one another. When considering TP and eliminating the variables most highly correlated with TP (i.e. chl $a$, TKN and TKN:TP), the best multiple regression model that could predict in situ PC abundance was as follows:

$$
\begin{aligned}
\log \mathrm{PC} \text { abundance } & =3.92+0.57 \log \mathrm{SRP}+0.34 \mathrm{Loss} \\
& +0.26 \log \text { conductivity }
\end{aligned}
$$

with $\mathrm{r}^{2}=0.39, \mathrm{p}<0.001$. When chl a rather than TP was considered, and the variables highly correlated with chl a were removed from the analysis (i.e. TP, TKN, Secchi, LAC), the resulting model was similar but included the TKN:TP ratio:

$$
\begin{array}{r}
\log \mathrm{PC} \text { abundance }=3.53+0.66 \log \mathrm{SRP}+0.36 \mathrm{Loss} \\
+0.36 \log \text { conductivity }+0.003 \mathrm{TKN}: \mathrm{TP}
\end{array}
$$

with $\mathrm{r}^{2}=0.44, \mathrm{p}<0.001$. Both these models explained less than half of the variation in TP, but both indicated the statistical importance of SRP and loss rates, which together explained most of the variation in PC abundance. Although the growth rate was highly correlated with loss rate (Fig. 2), when growth was included in the analysis rather than loss, the resulting model had much less predictive power, and growth was not a significant variable. Growth rates in contrast to loss rates were largely independent of the in situ PC concentrations (Table 3).

\section{DISCUSSION}

The goals of this study were to identify the main variables related to the in situ abundance of PC across a trophic gradient in lakes. While initially we hoped to cover a wide range of TP concentrations, the lakes sampled in Eastern Ontario and Western Quebec were more typical of ultra-oligotrophic to mesotrophic lakes by international standards (Kalff 2002). The final suite of lakes was in fact quite representative of lakes in the region, according to a broader survey of 600 lakes conducted the same summer by the Ontario Ministry of the Environment (Gemza \& Griffiths 2001). The guidelines of the Ontario Ministry consider lakes to be eutrophic when eplimnetic TP concentrations exceed $20 \mu \mathrm{g} \mathrm{l}^{-1}$. Only 8 of the 48 lakes or 50 lake sites had TP concentrations above this value. Even though we went further afield to upper New York State to sample more eutrophic lakes, these were still on the lower end of eutrophic lake classifications.
The observed variation in the in situ abundance of PC showed a slight trend with increasing TP over this oligotrophic to mesotrophic gradient, but the relationship was clearly not significant (Fig. 1). Oneida lake stands out from the other lakes in that PC were found in only trace amounts: this lake was dominated by a large monospecific cyanobacterial bloom of Aphanizomenon spp. during the summer of 2000. PC were also essentially absent in hypereutrophic Lake Rotognaio (New Zealand) when a monospecific bloom of Anabaena spp. was present (Pick 1991) and in Lake 227 of the Experimental Lakes Area, Ontario, when large monospecific blooms of cyanobacteria were present (F. R. Pick unpubl.). Although more specific studies are required, the presence of bloom forming cyanobacteria may help explain why some eutrophic lakes have very high levels of PC while others only have traces (Vörös et al. 1998).

In the present data set, the lack of sufficient highly eutrophic lakes did not allow for a test of the curvilinear relationship described by Pick (2000) for a much broader range of TP (up to $294 \mu \mathrm{g} \mathrm{l}^{-1}$ ). Declines in PC abundance were observed in systems with TP approximately above $20 \mu \mathrm{g}^{-1}$. Few of the lakes in the present study were above $20 \mu \mathrm{g} \mathrm{l}^{-1} \mathrm{TP}$. The absence of highly eutrophic lakes might also explain why light transparency was not a significant variable as described in Pick (1991).

With respect to nitrogen, PC also showed a slight trend of increasing abundance with TKN, with a correlation coefficient higher than that for TP; however, the relationship was also not statistically significant. Dissolved forms of nitrogen also showed no relationship with PC. In marine studies of APP, Agawin et al. (2000) did not detect a clear trend between APP biomass and nitrate levels.

In experimental studies that have examined the effects of nutrients on PC abundance in individual lakes, results have varied depending on the starting conditions and the complexity of the food chains. The addition of both nitrogen and phosphorus to large enclosures in an oligotrophic to mesotrophic lake (TP of $6 \mu \mathrm{g} \mathrm{l}^{-1}$ ) generally caused an overall decline in PC abundance with the exception of shallow enclosures with planktivorous fish (Tzaras et al. 1999). When all treatments were examined, a curvilinear relationship with respect to TP best described the response of PC, with $\mathrm{PC}$ increasing and then decreasing at an intermediate level of phosphorus (Pick 2000).

Case studies of lakes that have undergone changes in nutrient loading are also informative. In the ultraoligotrophic British Columbia lakes, fertilisation for salmon enhancement led to increases in PC abundance (Stockner \& Shortreed 1991). In contrast, in eutrophic Lake Maggiore, as nutrient levels declined 
due to remediation efforts, the abundance of PC gradually increased (Stockner et al. 2000).

In this study, of all the variables examined, SRP was the single variable correlated with PC and SRP that was important in the multiple regression models. This result was somewhat surprising given that SRP values were at detection in many lakes and SRP is not related to within lake seasonal changes in PC abundance (Pick \& Agbeti 1991). SRP is generally at detection in oligotrophic to mesotrophic lakes because of high algal demand and rapid turnover of the pool of available phosphate. Furthermore, SRP is not an accurate measure of available phosphate (Hudson et al. 2000). It should be noted that SRP was also highly correlated with $\mathrm{pH}$, and there are several reports of $\mathrm{pH}$ effects on PC abundance (Stockner et al. 2000). It seems that PC are sensitive to acidic conditions, and the present study included some slightly acidic lakes. As a result, it is not possible to determine whether SRP or $\mathrm{pH}$ was responsible for the observed effects. Conductivity also entered into the multiple regression models. Conductivity in these lakes is largely related to calcium concentrations, and hence pH. Similarly, in a study of 6 lakes in Quebec, Pinel-Alloul et al. (1996) showed a positive effect of conductivity and $\mathrm{pH}$ on APP biomass.

The TKN:TP ratio was a significant variable in the second multiple regression model but was of relatively minor importance compared to SRP and the loss rate. The TKN:TP ratio was negatively related to TP in the study lakes so that the ratio may simply be reflecting changing phosphorus conditions. Wehr (1989) was not able to identify through experimentation an N:P ratio that favoured Synechococcus spp. dominance in freshwater.

In the present study there was no effect of water temperature on abundance, growth or loss rates as might be expected from studies in the marine environment (Ning \& Vaulot 1992, Agawin et al. 1998). The lack of a temperature effect was more that likely due to the narrow range found during the summer months (19 to $\left.25^{\circ} \mathrm{C}\right)$.

The results obtained on growth and loss suggest a strong linear relationship between those 2 rates (Fig. 2). This correlation is consistent with the purported interaction between microbial predators and their prey. Grazing may exert positive effects on growth through the release of dissolved nutrients, which are then rapidly re-assimilated by microorganisms. In estuarine water, Sherr et al. (1986) invoked this mechanism to explain a positive relationship between abundance of heterotrophic bacteria and grazing from heterotrophic nanoflagellates. Whether cyanophage-induced cell lysis has the same effect on nutrient cycling has not been studied. Laboratory experiments have convincingly demonstrated that flagellate grazing can stimulate heterotrophic bacterial growth rates in several freshwater strains (Hahn et al. 1999).

In the present study, there was no significant correlation between growth rates per se and any form of dissolved phosphorus or nitrogen. The relationship of growth with TP was close to statistical significance and the correlation coefficient was higher than that for loss rates, which was opposite to our initial hypothesis. While we expected hyperbolic relationships with nutrients, such models did not provide a better fit to the data.

We anticipated an effect of nutrients on growth rates from both culture work and field experiments. Liu et al. (1998) observed an increase in the growth rate of marine Synechococcus spp. with nitrate concentration, and Rhew \& Ochs (2000) also observed nitrogen limitation of APP growth rate (prokaryotes and eukaryotes) from riverine samples in an American reservoir.

In some lakes, the estimated growth or loss rates were negative, suggesting that cell division occurred in samples treated with ampicillin or that losses of PC were higher in control samples relative to loss rates estimated in the ampicillin treatments. Since the experimental method was applied in the same way for each lake, we cannot explain these unrealistic rates. The PC strains studied to date are all sensitive to ampicillin (Campbell \& Carpenter 1986), but it is conceivable that other as-yet untested species or strains are resistant to this antibiotic. It has been noted that cell division is not inhibited in Prochlorococcus spp. by ampicillin (Liu et al. 1995). We used an ampicillin concentration that should not affect eukaryotes (Campbell \& Carpenter 1986, Ning \& Vaulot 1992). However, it is still possible that some members of the grazing assemblage were in fact affected by the ampicillin. If the negative growth and loss rates are not taken into consideration, the estimated growth and loss rates are very similar to those in the literature regardless of the method used (Weisse 1993). It should be noted that ampicillin blocks synthesis of the cell wall in dividing cyanobacteria and in many heterotrophic bacteria as well, but the consequences of this on the overall grazing rate are not known.

Several techniques have been developed for the measurement of growth and loss rates. Landry (1994) evaluated these techniques and grouped them into 3 categories: (1) techniques that infer the rates from natural populations in situ (e.g. the frequency of dividing cells); (2) techniques employing tracers (e.g. fluorescently labelled prey); and (3) community manipulations (e.g. dilution and selective metabolic inhibitor techniques). Each technique has advantages and disadvantages. The selective metabolic inhibitor technique is among the simplest techniques in that it requires fewer samples and entails perhaps the fewest 
assumptions. However, in situations where PC abundance is very low, the technique is difficult to apply and the grazing rate is likely underestimated. The addition of fluorescently labelled bacteria (FLB) has been proposed as an internal control (Liu et al. 1995). However, the choice of FLB can be problematic, and FLB per se would be poor surrogates for PC. An appropriate culture of PC of the correct dimension and with different fluorescence characteristics from in situ populations would be required for each lake.

The selective inhibitor technique does not allow for identification of the actual loss processes, which would include grazing, viral infection, autolysis of cells due to aging, and apoptosis. All of these processes would tend to increase with population size. It is generally believed that grazing is the main factor responsible for PC losses in freshwater and marine environments (Stockner et al. 2000). In this study, the overall loss rates for PC averaged about $33 \% \mathrm{~d}^{-1}$ among the lakes but were as high as $70 \% \mathrm{~d}^{-1}$ in 1 lake. Suttle \& Chan (1994) estimated that Synechococcus spp. lysis by cyanophages ranged from only 5 to $14 \% \mathrm{~d}^{-1}$ in the marine environment. Unfortunately there are no analogous estimates of viral induced cell lysis in lakes. Future studies should take into consideration all loss processes to determine specifically the role of grazing per se.

The present study suggests that loss rates of PC and SRP were the most important variables related to the in situ PC abundance. Even though growth rate was highly correlated with the loss rate, only the latter was significantly correlated with in situ PC abundance. These relationships suggest that biotic factors may be as important as, if not more important than, abiotic factors in controlling the abundance of PC, at least in oligotrophic to mesotrophic lakes. However, the multiple regression models accounted for only about $44 \%$ of the variation in PC among the lakes. While some of the unexplained variation would be due to sampling and measurement errors, another reason may be that PC were considered collectively as 1 functional group responding to the same suite of environmental variables. This assumption may be quite incorrect; there is likely considerable taxonomic and hence ecological diversity within freshwater PC that remains to be explored.

Acknowledgements. We would like to thank all the people who assisted in the collection of samples and with the experiments, but particularly Christian Doyon. We also thank Euan D. Reavie for providing background data on the Rideau lakes, as well as members from the Groupe de Recherche Interuniversitaire en Limnologie (GRIL) for background data on the lakes of the Laurentians and Estrie (B. Pinel-Alloul, Y. Prairie and R. Carignan). This work was funded by an NSERC Canada operating grant to F.R.P. We thank 2 anonymous reviewers for their constructive comments.

\section{LITERATURE CITED}

Agawin NRS, Duarte CM, Agustí S (1998) Growth and abundance of Synechococcus sp. in a Mediterranean bay: seasonality and relationship with temperature. Mar Ecol Prog Ser 170:45-53

Agawin NRS, Duarte CM, Agustí S (2000) Nutrient and temperature control of the contribution of picoplankton to phytoplankton biomass and production. Limnol Oceanogr 45:591-600

Azam F, Fenchel F, Field JG, Meyer-Reid LA, Thingstad F (1983) The ecological role of water-column microbes in the sea. Mar Ecol Prog Ser 10:257-263

Burnison BK (1980) Modified dimethyl sulfoxide (DMSO) extraction for chlorophyll a analysis of phytoplankton. Can J Fish Aquat Sci 37:729-733

Campbell L, Carpenter EJ (1986) Estimating the grazing pressure of heterotrophic nanoplankton on Synechococcus spp. using the sea water dilution and selective inhibitor techniques. Mar Ecol Prog Ser 33:121-129

Fahnenstiel GL, Carrick HJ (1992) Phototrophic picoplankton in lakes Huron and Michigan: abundance, distribution, composition, and contribution to biomass and production. Can J Fish Aquat Sci 49:379-388

Gaedke U, Weisse T (1998) Seasonal and interannual variability of picocyanobacteria in Lake Constance (1987-1997). Arch Hydrobiol Spec Issues Adv Limnol 53: $143-158$

Gemza A, Griffiths P (2001) Lake Partner Program: a summary of year 2000 water quality findings. Ontario Ministry of the Environment, Toronto

Hahn MW, Moore ERB, Hölfe MG (1999) Bacterial filament formation, a defense mechanism against flagellate grazing, is growth rate controlled in bacteria of different phyla. Appl Environ Microbiol 65:25-35

Hall JA, Barrett DP, James MR (1993) The importance of phytoflagellate, heterotrophic flagellate and ciliate grazing on bacteria and picophytoplankton sized prey in a coastal marine environment. J Plankton Res 15:1075-1086

Hudson JJ, Taylor WD, Schindler DW (2000) Phosphate concentrations in lakes. Nature 406:54-56

Jeffrey SW, Humphrey GF (1975) New spectrophotometric equations for determining chlorophylls $a, b, c 1$ and $c 2$ in higher plants, algae and natural phytoplankton. Biochem Physiol Pflanz 167:191-194

Kalff J (2002) Limnology: inland water ecosystems. PrenticeHall, Upper Saddle River

Komárek J (1996) Towards a combined approach for the taxonomic and species delimitation of picoplanktonic cyanoprokaryotes. Algol Stud 83:377-401

Landry MR (1994) Methods and controls for measuring the grazing impact of planktonic protists. Mar Microb Food Webs 8:37-58

Liu H, Campbell L, Landry MR (1995) Growth and mortality rates of Prochlorococcus and Synechococcus measured with a selective inhibitor technique. Mar Ecol Prog Ser 116:277-287

Liu H, Campbell L, Landry MR, Nolla HA, Brown SL, Constantinou J (1998) Prochlorococcus and Synechococcus growth rates and contributions to production in the Arabian Sea during the 1995 Southwest and Northeast Monsoons. Deep-Sea Res II 45:2337-2352

Müller H (1996) Selective feeding of a freshwater chrysomonad, Paraphysomonas sp., on chroococcoid cyanobacteria and nanoflagellates. Arch Hydrobiol Spec Issues Adv Limnol 48:63-71

Ning X, Vaulot D (1992) Estimating Synechococcus spp. 
growth rates and grazing pressure by heterotrophic nanoplankton in the English Channel and the Celtic Sea. Acta Oceanol Sin 11:255-273

Pick FR (1991) The abundance and composition of freshwater picocyanobacteria in relation to light penetration. Limnol Oceanogr 36:1457-1462

Pick FR (2000) Predicting the abundance and production of photosynthetic picoplankton in temperate lakes. Verh Int Ver Limnol 27:1884-1889

Pick FR, Agbeti M (1991) The seasonal dynamics and composition of photosynthetic picoplankton communities in temperate lakes in Ontario, Canada. Int Rev Ges Hydrobiol 76:565-580

Pick FR, Caron DA (1987) Picoplankton and nanoplankton biomass in lake Ontario: relative contribution of phototrophic and heterotrophic communities. Can J Fish Aquat Sci 44:2164-2172

Pinel-Alloul B, Bourbonnais N, Dutilleul P (1996) Among-lake and within-lake variation of autotrophic pico- and nanoplankton biomass in six Quebec lakes. Can J Fish Aquat Sci 53:2433-2445

Raven JA (1998) The twelfth Tansley Lecture. Small is beautiful: the picophytoplankton. Funct Ecol 12:503-513

Regional Municipality of Ottawa-Carleton (1993) Surface water quality technical report 1993. Regional Municipality of Ottawa-Carleton, Surface Water Quality Branch, Ottowa

Rhew K, Ochs CA (2000) Spatial patterns in autotrophic picoplankton abundance in a reservoir examined using microcosm experiments. Int Rev Ges Hydrobiol 85: 395-412

Rippka R (1988) Recognition and identification of cyanobacteria. Methods Enzymol 167:28-67

Sherr BF, Sherr EB, Andrew TL, Fallon RD, Newell SY (1986) Trophic interactions between heterotrophic protozoa and bacterioplankton in estuarine water analyzed with selective metabolic inhibitors. Mar Ecol Prog Ser 32:169-179

Editorial responsibility: William Li, Dartmouth, Nova Scotia, Canada
Søndergaard M (1991) Phototrophic picoplankton in temperate lakes: seasonal abundance and importance along a trophic gradient. Int Rev Ges Hydrobiol 76:505-522

Stockner JG, Antia NJ (1986) Algal picoplankton from marine and freshwater ecosystems: a multidisciplinary perspective. Can J Fish Aquat Sci 43:2472-2503

Stockner JG, Shortreed KS (1991) Autotrophic picoplankton: community composition, abundance and distribution across a gradient of oligotrophic British Columbia and Yukon Territory lakes. Int Rev Ges Hydrobiol 76:581-601

Stockner J, Callieri C, Cronberg G (2000) Picoplankton and other non-bloom-forming cyanobacteria in lakes. In: Whitton BA, Potts M (eds) The ecology of cyanobacteria: their diversity in time and space. Kluwer Academic Publishers, Dordrecht, p 195-231

Suttle CA, Chan AM (1994) Dynamics and distribution of cyanophages and their effect on marine Synechococcus spp. Appl Environ Microbiol 60:3167-3174

Tzaras A, Pick FR, Mazumder A, Lean DRS (1999) Effects of nutrients, planktivorous fish and water column depth on components of the microbial food web. Aquat Microb Ecol 19:67-80

Vörös L, Callieri C, Balogh KV, Bertoni R (1998) Freshwater picocyanobacteria along a trophic gradient and light quality range. Hydrobiologia 369-370:117-125

Wehr JD (1989) Experimental tests of nutrient limitation in freshwater picoplankton. Appl Environ Microbiol 45: 1196-1201

Wehr JD (1991) Nutrient and grazer-mediated effects on picoplankton and size structure in phytoplankton communities. Int Rev Ges Hydrobiol 76:643-656

Weisse $\mathrm{T}$ (1988) Dynamics of autotrophic picoplankton in Lake Constance. J Plankton Res 10:1179-1188

Weisse T (1993) Dynamics of autotrophic picoplankton in marine and freshwater ecosystems. Adv Microb Ecol 13: $327-370$

Submitted: June 15, 2001; Accepted: December 18, 2001

Proofs received from author(s): February 7, 2002 